\section{Diseases of Cereals}

CoRReCT diagnosis is of prime importance for the successful prevention and control of plant disease, and considerable confusion is frequently caused by the loose use of terms such as 'blight', 'rust' or 'mildew'. The Ministry of Agriculture has accordingly published Bulletin No. 129, compiled by W. C. Moore, entitled "Cereal Diseases" (London : H.M. Stationery Office. 1s. net), which should prove of great value to all interested in the cultivation of these crops, whether it be the farmer, scientific adviser or student of agriculture. It provides simple, accurate and, in a number of cases, illustrated descriptions of the diseases of cereals that occur in Great Britain, together with the measures that should be taken to prevent or control their incidence. The diseases causing the most damage are yellow rust, bunt of wheat, leaf spot of oats, leaf stripe of barley, take-all, eyespot, mildew and manganese deficiency disease; but even these vary in intensity from season to season and in some years others are of equal importance. A farmer experiencing trouble with cereal crops is urged to seek advice from his County War Agricultural Committee, and a list of provincial advisory centres and advisory mycologists is appended from whom help may be obtained.

\section{Californian Marine Algæ and Grasses}

E. YaLE Dowsen has compiled a most useful "Annotated List of the Marine Algæ and Marine Grasses of San Diego, California" (Occas. Papers, San Diego Society: of Natural History, No. 7, March 1945). This is intended primarily for the amateur, and is simplified as much as possible. Directions are given for collecting, preserving and examining marine algæ, and there are also keys to genera and list of species with habitats, notes on marine grasses, a glossary of terms and a bibliography. With this little manual much may be accomplished by anyone interested in these plant groups.

\section{Royal Society of Edinburgh}

The following have been elected officers and members of council of the Royal Society of Edinburgh: President: Sir W. Wright Smith; VicePresidents : Dr. Alan W. Greenwood, Dr. E. Hindle, Dr. David Russell, Prof. R. J. D. Graham, the Right Hon. Lord Cooper, Prof. J. W. Heslop Harrison; General Secretary : Prof. James Kendall ; Secretaries to Ordinary Meetings : Prof. E. T. Copson, Prof. A. Holmes; Treasurer : Sir E. Maclagan Wedderburn ; Curator: Dr. John E. Mackenzie; Councillors : Lieut.-Colonel W. F. Harvey, Prof. A. E. Trueman, Prof. J. Walton, Prof. T. Alty, Mr. J. Morrison Caie, Sir Robert Muir, The Hon. Lord Birnam, Prof. E. P. Cathcart, Prof. A. Gray, Dr. J. Russell Greig, Dr. W. A. Harwood and Prof. C. M. Yonge.

\section{University of London}

THE following appointments have been made by the University of London: Dr. A. I. Richards, special lecturer in social anthropology at the London School of Economics, has been appointed to the University readership in anthropology tenable at the School as from October 1. Dr. Margaret Read, lecturer in social anthropology at London School of Economics and since 1940 head of the Colonial Department at the Institute of Education, has been appointed to the University readership in education tenable at the Institute of Education as from October 1.
Dr. James Henderson, lecturer in mathematics at King's College, London, has been appointed academic registrar of the University as from January 1, 1946, in succession to Colonel S. J. Worsley, who has been appointed principal of the College of Estate Management.

The following doctorates have been conferred: D.Sc. on Robert Brown (Imperial College); D.Sc. (Eng.) on C. M. White (Imperial College); D.Sc. (Eng.) on Norman Davey.

\section{Announcements}

THE Nobel Prize for Medicine for 1945 has been awarded jointly to Sir Alexander Fleming, of the University of London, Sir Howard Florey and Dr. E. B. Chain, of the University of Oxford, for their work on the discovery and utilization of penicillin.

SIR JoHN Boyd ORR has been appointed the first director-general of the United Nations Food and Agricultural Organization.

DR. H. LIPSON, of the Cavendish Laboratory, Cambridge, has been appointed head of the Department of Physics in the Manchester College of Technology in succession to Dr. W. H. Taylor.

Prow. L. P. GARRod, professor of bacteriology in the University of London, is visiting Belgium to lecture on penicillin to medical audiences, at the invitation of the University of Louvain and under the auspices of the British Council.

THE British Association announces the reopening of the Charles Darwin memorial rooms at Down House, Downe, Kent, daily excepting Fridays, from 11 a.m. to 5 p.m. The exhibits were uninjured during the War, and since they were last on view a number of additions have been made.

THE Council of the Geological Society of London has accepted an offer made jointly by the AngloIranian and the Burmah Oil Companies to provide a fund of $£ 750$ per annum, for an initial period of seven years, to be used to defray the costs of an instructional tour for about twenty students taking honours courses in geology at various universities and colleges. Each tour will probably extend over three weeks and will include visits to classic geological sections. It will be arranged to supplement the field instruction normally provided by the universities.

Dr. E. W. GuDGer, Department of Fishes, American Museum of Natural History, New York City 24, N.Y., states that the "Bashford Dean Memorial Volume: Archaic Fishes" is now complete in Articles I-VIII, plus index, introduction, two title pages and two tables of contents-for binding as Parts I and II. Those who receive such material regularly from the American Museum are invited to apply for any parts which may be missing. Duplicate lithographed plates of the segmentation of the egg (2) and of the genital system of Bdellostoma (4) are also available.

Reference was made in Nature of October 27 (p. 502) to the commemoration of the anniversary of the discovery of $\mathrm{X}$-rays. The joint meeting of all the participating societies will be beld at the Phoenix Theatre, Charing Cross Road, London, W.C.2, on November 9, at 3.30 p.m., instead of at the Central Hall, Westminster, as originally arranged. There will also be a small exhibition of historical apparatus in the Reid Knox Hall of the British Institute of Radiology, 32 Welbeck Street, London, W.1, during November $8-10$ (10 a.m. -6 p.m.). 